\title{
Utilization of Organic Fertilizer on Sweet Corn (Zea mays saccharata Sturt) Crop at Shallow Swamp Land
}

\author{
Midranisiah $^{1, *}$, Neni Marlina ${ }^{2}$, S.E Rahim ${ }^{2}$, and Erni Hawayanti ${ }^{3}$ \\ ${ }^{1}$ STIPER Sriwigama of Palembang, Jl. Demang IV Demang Lebar Daun Lorok Pakjo IB 1Palembang \\ Indonesia \\ ${ }^{2}$ Faculty of Agriculture, Palembang University, Jl.Darmapala No 1A Bukit Lama Palembang \\ Indonesia \\ ${ }^{3}$ Faculty of Agriculture, Muhammadiyah University, Palembang, Jl Jend. A.Yani 13 Ulu Palembang \\ Indonesia
}

\begin{abstract}
Shallow lowland swamp area has significant potential for cultivation of sweet corn crop. This lowland swamp has rich natural resources such as organic fertilizers from chicken dunk, cow dunk, oil palm fresh bunches and legume cover crops (LCC) that are not maximally utilized yet by farmers. These organic fertilizers can be utilized to increase the growth and production of sweet corn crop. The research objective was to determine organic fertilizer types that capable to increase the growth and production of sweet corn crop at shallow lowland swamp area. This research had been conducted from January to April 2015 in Pulau Semambu Village, North Indralaya Subdistrict, Ogan Ilir District, South Sumatra Province. The design used in this research was non-factorial Randomized Block Design (RBD) with four treatments of organic fertilizer types with six replications for each treatment. The treatments were consisted of organic fertilizers from chicken dunk, cow dunk, oil palm fresh bunches and legume cover crops (LCC). The results showed that treatment of organic fertilizers from chicken dunk could increase the growth and production of sweet corn at shallow lowland swamp area with yield level of $4.37 \mathrm{~kg} \cdot \mathrm{plot}^{-1}$.
\end{abstract}

\section{Introduction}

Area of lowland swamp in Indonesia is estimated about 13.28 million ha which consisted of 4.167 millions ha of shallow lowland swamp, 6.075 million ha of intermediate lowland swamp and 3.038 million ha of deep lowland swamp. It is estimated that lowland swamp which has potential for agricultural area was about 10.19 million ha, but only about 1.55 million ha that had already been opened and about 0.729 million ha had been utilized for agricultural enterprise. This lowland swamp generally is located in Sumatra, Kalimantan and Papua. From the magnitude of this utilized lowland swamp, only about 694.294 ha was

\footnotetext{
* Coresponding Author: marlina002@yahoo.com
} 
planted with rice crop and only about 62.844 ha was planted with rice crop having two times planting per year. Therefore, very extensive area of lowland swamp is available to be utilized for agriculture enterprise [1].

Lowland swamp can be classified as shallow lowland swamp, intermediate lowland swamp and deep lowland swamp. Shallow lowland swamp generally has better soil fertility level than that of intermediate lowland swamp and deep lowland swamp because of enrichment from mud sediment carried by river water outflow. Shallow lowland swamp has high potential for agricultural enterprise of food crops and horticulture crops, especially rice in wet season and second crops as well as seasonal vegetables and fruits [2]. One of this potential crop is sweet corn.

Sweet corn crop will not produce maximum yield if its nutrients requirement are insufficient. Fertilization can increase harvest yield quantitatively and qualitatively. Lingga and Marsono [8] stated that fertilizer is key point of soil fertility because fertilizer contains one or more nutrients to substitute the exhausted nutrients absorbed by crop.

Fertilizers used in this research was organic fertilizers which consisted of organic fertilizers from chicken dunk, cow dunk, oil palm fresh bunches and legume cover crops (LCC). According to Suriadikarta and Simanungkalit [23], organic fertilizer is fertilizer that mostly or all of its components is consisted of organic matters originated from crops or animals that had been processed, in solid or liquid form which can be used to supply organic matters for improvement of physical, chemical and biological properties of soil. Improvement of physical, chemical and biological properties of soil can provide better growth environment for roots and addition of macro and micro nutrients from organic fertilizers can increase production of sweet corn crop.

Some previous studies had been done in term of organic fertilizers usage (such as plus organic fertilizer, bio-fertilizer, rice straw compost enriched with microbe or bio-organic fertilizer, chicken dunk fertilizer, swamp grass compost) on crops such as food crops (rice, corn and nuts), vegetable crops (sweet corn, cucumber, tomato and others) in shallow and deep lowland swamp areas as well as in tidal lowland of C-type flooding. Results of study by Marlina et al. [10-15] and [26] showed that plus organic fertilizer at dose of $750 \mathrm{~kg} / \mathrm{ha}$ combined with organic pesticides (animal and vegetation sources), bio-organic fertilizer at dose of $225 \mathrm{~kg} / \mathrm{ha}$ to $300 \mathrm{~kg} / \mathrm{ha}$ and $0 \%$ to $75 \%$ recommended dose of inorganic fertilizer was capable to increase rice production in shallow lowland swamp with magnitude of 2.16 $\mathrm{kg} / \mathrm{plot}$.

Bio-organic fertilizer at dose of $300 \mathrm{~kg} / \mathrm{ha}$ and $75 \%$ recommended dose of inorganic fertilizer gave rice production of $93.67 \mathrm{~g} /$ pot. Bio-organic fertilizer at dose of $200 \mathrm{~kg} / \mathrm{ha}$ could increase production of hybrid corn in shallow lowland swamp. Combination of $75 \%$ bio-organic fertilizer and $25 \%$ recommended dose of inorganic fertilizer could increase rice production with magnitude of $48.56 \mathrm{~g} /$ pot. Addition of formula 9 plus organic fertilizer could increase rice production with magnitude of $5 \mathrm{~kg} / \mathrm{plot}$. Grass swamp compost could increase production of red pepper and cucumber with magnitude of $20.48 \mathrm{~kg} / \mathrm{raft}$ and 21.44 $\mathrm{kg} / \mathrm{raft}$, respectively. The use of chicken dunk fertilizer at dose of 10 ton/ha was capable to increase peanut production with magnitude of $2.73 \mathrm{~kg} / \mathrm{plot}$.

\section{Research method}

This research had been conducted from January to April 2015 in Pulau Semambu Village, North Indralaya Subdistrict, Ogan Ilir District, South Sumatra Province. The design used in this research was non-factorial Randomized Block Design (RBD) with four treatments of organic fertilizer types with six replications for each treatment. The treatments were 
consisted of organic fertilizers from chicken dunk, cow dunk, oil palm fresh bunches and legume cover crops (LCC).

\subsection{Land preparation}

Land or area that had been measured was subsequently cleaned from weeds and the existing crop residues. Land clearing was done manually by using equipments such as chopping knife, mattock and others and followed by plot development with dimension of 1 $\mathrm{m} \times 3 \mathrm{~m}$ consisting of 36 plots with inter plot distance of $1 \mathrm{~m}$. Land preparation was conducted 2 weeks before planting operation.

\subsection{Soil tillage}

Soil was tilled by using mattock until loose in order to improve soil structure, air circulation within soil and facilitate soil microbe activity.

\subsection{Fertilizing}

Fertilizing of crop was done according to the treatments in which the used fertilizers were consisted of organic fertilizers from chicken dunk, cow dunk, oil palm fresh bunches and legume cover crops (LCC) with respective dose of $5 \mathrm{ton} / \mathrm{ha}(1.5 \mathrm{~kg} / \mathrm{plot})$, given one week before planting which was uniformly distributed and subsequently covered with soil. Inorganic fertilizer as base fertilizer in form of combined NPK fertilizer at dose of 150 $\mathrm{kg} / \mathrm{ha}(45 \mathrm{~g} / \mathrm{plot})$ was given at planting time.

\subsection{Planting}

Seeds were planted by putting 2 seeds per planting hole with planting distance of $75 \mathrm{~cm} \mathrm{x}$ $25 \mathrm{~cm}$. Each plot consisted of 12 plants.

\subsection{Maintenance}

Crop maintenance was consisted of thinning out, irrigation, weeds control, and heaping. Thinning out was done two weeks after planting in which one planting hole only consisted of one plant. Irrigation was done every day, especially during vegetative growth stage or during plant ages of one up to eight weeks. Weed controls was done according to requirement and condition in land itself, whereas heaping was done in order to strengthen the plant upright.

\subsection{Harvesting}

Harvesting was done when the plant ages was about 60 days after planting (DAP) which characterized by appearance of brown hairs of corn, corn ears were still soft and fully fill up.

\subsection{The observed parameters}


The observed parameters were consisted of soil's chemical properties before planting, analyses of C-organic, N, P and $\mathrm{K}$ within respective organic fertilizers, crop height $(\mathrm{cm})$, leave numbers (sheet), stem of an ear of corn length $(\mathrm{cm})$, stem of an ear of corn diameter $(\mathrm{cm})$, stem of an ear of corn weight per crop $(\mathrm{g})$, stem of an ear of corn weight per plot $(\mathrm{kg})$ and dry matter weight $(\mathrm{g})$.

\section{Results and discussion}

Based on analysis results of soil chemical properties conducted before research implementation and criteria [18] as well as [22], soil used in this study can be classified as acid soil $\left(\mathrm{pH} \mathrm{H}_{2} \mathrm{O}=4.81\right)$ with low level of cation exchange capacity $(13.53 \mathrm{me} / 100 \mathrm{~g})$, medium level of C-organic content of $2.67 \%$, medium level of $\mathrm{N}$-total content of $0.22 \%$, very high level of available $\mathrm{P}$ (180.37 ppm), exchanged base such as Ca-dd (1.04 me/100g) was very low, Mg-dd $(0.28 \mathrm{me} / 100 \mathrm{~g})$ was very low, K-dd $(0.21 \mathrm{me} / 100 \mathrm{~g})$ was very low, Na-dd $(0.53 \mathrm{me} / 100 \mathrm{~g})$ was very low, base saturation $(15.23 \%)$ was very low, Al-dd was $1.96 \mathrm{me} / 100 \mathrm{~g}$ with soil texture consisting of $62.42 \%$ sand, $17.00 \%$ loam and $20.00 \%$ clay so that this soil can be classified as sandy loam.

Sandy loam soil which contains higher percentage of sand than that of loam and clay has porous characteristics so that addition of organic fertilizer will bind soil particles firmly which in turn capable to store water containing more nutrients and subsequently available for sweet corn crop.

Although C-organic content of soil before planting was $2.67 \%$ (classified as medium), organic fertilizer is still needed for sweet corn cultivation because nutrients content within soil will decrease along with time so that it is expected that addition of organic matter in form of chicken dunk, cow dunk, oil palm fresh bunches and legume cover crops (LCC) will improve soil fertility which related to physical, chemical and biological properties of soil in the long term. This is in accordance to statement from [6] and [3] which showed that organic matter is important element for development of soil fertility. Organic matter in general can improve soil physical, chemical and biological properties. Organic matter improves soil physical property through development of loose and crumbly condition of soil particles which provide better aeration so that crop's root can easily penetrate into soil. Organic matter in sandy soil will increase the bonding amongst soil particles and improve water holding capacity. Soil chemical property is improved due to the increment of cation exchange capacity and nutrients availability, whereas soil biological property is improved due to addition of energy required for soil microorganism life [24].

Nutrients content within soil will decrease along with time because they are consumed by plant. This nutrients depletion condition should be recovered by addition of nutrients in order to prevent low level of crop growth and production. Lack of nutrients required by crop can be solved by fertilizer addition [25].

Analysis results of organic fertilizers used in this research was shown in Table 1. These organic fertilizers had diverse $\mathrm{C} / \mathrm{N}$ ratio content. $\mathrm{C} / \mathrm{N}$ ratio value of chicken dunk organic fertilizer was lower (21.58) than $\mathrm{C} / \mathrm{N}$ ratio values of organic fertilizers from cow dunk, oil palm fresh bunches and legume cover crops (LCC). This fact showed that chicken dunk organic fertilizer had higher decomposition rate and capable to provide balance and sufficient nutrients of N, P and $\mathrm{K}$ for sweet corn crop. This is in accordance to statement from [9] which showed that optimum growth and production of corn crop require sufficient nutrients, especially $\mathrm{N}, \mathrm{P}$ and $\mathrm{K}$. 
In addition, lower value of $\mathrm{C} / \mathrm{N}$ ratio of chicken dunk organic fertilizer than that of other organic fertilizers used in this study showed the occurrence of mineralization process (the change from organic state to inorganic state). Mineralization process will release $\mathrm{N}$ nutrient and others resulting in increase of $\mathrm{N}$ nutrient availability within soil. This is in accordance to statement from [27] which showed that chicken dunk organic fertilizer had relatively faster decomposition rate than other organic fertilizers based on the same weight unit.

Table 1. N, P and $\mathrm{K}$ nutrients content and $\mathrm{C} / \mathrm{N}$ ratio of organic fertilizer types.

\begin{tabular}{|l|c|c|c|c|}
\hline $\begin{array}{l}\text { Organic } \\
\text { fertilizer types }\end{array}$ & N total (\%) & P total (\%) & K total (\%) & C/N ratio \\
\hline Chicken dunk & 1.07 & 3.61 & 0.91 & 21.58 \\
\hline Cow dunk & 2.27 & 1.81 & 2.47 & 25.53 \\
\hline $\begin{array}{l}\text { Oil palm fresh } \\
\text { bunches }\end{array}$ & 2.58 & 0.55 & 5.59 & 22.57 \\
\hline LCC & 1.54 & 2.55 & 2.34 & 27.31 \\
\hline
\end{tabular}

Results of study showed that treatment of chicken dunk organic fertilizer on sweet corn had produced higher leave numbers, longer stem of an ear of corn and higher stem of an ear of corn diameter than that of other organic fertilizers as well as had significantly different effect (Table 2). This was due to the fact that chicken dunk organic fertilizer had provided $\mathrm{N}, \mathrm{P}$ and $\mathrm{K}$ nutrients in sufficient and balance condition resulting in increase of crop height and leave numbers. Crop height affects leave numbers. Leave numbers on treatment by using chicken dunk organic fertilizer were higher than that of other organic fertilizers which in turn increase photosynthesis capacity. High photosynthesis capacity will increase dry matter weight of crop.

This dry matter is subsequently used for vegetative and generative growths. Jumin [7] had stated that dry matter is photosynthate storage in cells and tissues. Photosynthate or net yield of photosynthesis is the energy reduction due to respiration. Higher dry matter magnitude will produce higher photosyntate storage which in turn will determine photosynthate distribution magnitude (transfer of dry matter) into economic part of crop (stem of an ear of corn) indicated by stem of an ear of corn weight per crop and stem of an ear of corn weight per plot. Gardner et al. [4] showed that the higher photosynthate yield, the higher was the food supply storage transferred into seeds by assuming that other factors such as light, water, temperature and nutrients are in optimum condition.

Table 2. The effect of organic fertilizer types on vegetative growth of sweet corn crop.

\begin{tabular}{|l|c|c|c|c|}
\hline $\begin{array}{c}\text { Organic } \\
\text { fertilizer types }\end{array}$ & $\begin{array}{c}\text { Crop height } \\
(\mathbf{c m})\end{array}$ & $\begin{array}{c}\text { Leave numbers } \\
\text { (helai) }\end{array}$ & $\begin{array}{c}\text { Stem of an ear } \\
\text { of corn length } \\
(\mathbf{c m})\end{array}$ & $\begin{array}{c}\text { Stem of an } \\
\text { ear of corn } \\
\text { diameter } \\
\text { (cm) }\end{array}$ \\
\hline Chicken dunk & $187.67 \mathrm{c}$ & $11.33 \mathrm{c}$ & $22.15 \mathrm{~d}$ & $4.21 \mathrm{~b}$ \\
\hline Cow dunk fresh & $177.25 \mathrm{~b}$ & $10.75 \mathrm{~b}$ & $20.78 \mathrm{c}$ & $4.05 \mathrm{a}$ \\
\hline $\begin{array}{l}\text { Oil palm fres } \\
\text { bunches }\end{array}$ & $137.41 \mathrm{a}$ & $9.83 \mathrm{a}$ & $17.44 \mathrm{a}$ & $3.99 \mathrm{a}$ \\
\hline LCC & $166.21 \mathrm{~b}$ & $10.08 \mathrm{a}$ & $18.83 \mathrm{~b}$ & $3.96 \mathrm{a}$ \\
\hline HSD 0.05 & 17.64 & 0.54 & 1.22 & 0.13 \\
\hline
\end{tabular}

Remarks:Number followed by the same letter in the same column showed not significantly different based on HSD test at $\alpha=5 \%$ 
In addition, average production of sweet corn per crop and per plot as well as dry matter weight were higher on treatment by using chicken dunk organic fertilizer than that of organic fertilizers of cow dunk, oil palm fresh bunches and LCC (Table 3). Dry matter weight produced on treatment by using chicken dunk organic fertilizer was higher and significantly different than that of treatment by using organic fertilizers of cow dunk, oil palm fresh bunches and LCC. This indicates that crop having higher dry matter weight will produce higher stem of ear corn weight per crop and per plot. This is in accordance to statement from [17] which showed that higher dry matter weight will produce higher stem of an ear of corn length, stem of an ear of corn diameter and husked stem of an ear of corn weight.

Table 3. The yield and dry matter weight of sweet corn crop related to several organic fertilizers treatment

\begin{tabular}{|l|c|c|c|}
\hline \multirow{2}{*}{$\begin{array}{l}\text { Organic } \\
\text { fertilizer types }\end{array}$} & \multicolumn{2}{|c|}{ Production } & $\begin{array}{l}\text { Dry matter } \\
\text { weight (g) }\end{array}$ \\
\cline { 2 - 3 } & per plant (g) & per plot (kg) & $65.39 \mathrm{~d}$ \\
\hline Chicken dunk & $284.52 \mathrm{c}$ & $4.37 \mathrm{c}$ & $55.47 \mathrm{c}$ \\
\hline Cow dunk & $219.49 \mathrm{~b}$ & $3.78 \mathrm{~b}$ & $34.82 \mathrm{a}$ \\
\hline $\begin{array}{l}\text { Oil palm fresh } \\
\text { bunches }\end{array}$ & $140.20 \mathrm{a}$ & $2.97 \mathrm{a}$ & $45.41 \mathrm{~b}$ \\
\hline LCC & $184.16 \mathrm{~b}$ & $3.23 \mathrm{a}$ & 9.06 \\
\hline HSD 0.05 & 42.16 & 0.48 & \\
\hline
\end{tabular}

Remarks: Numbers followed by the same letter in the same column showed not significantly different based on HSD test at $\alpha=5 \%$

During seed filling period, nitrogen and photosynthate transport from leaves section is very high in which nitrogen regulates phosphorus usage that stimulate flowering and seed formations. During this growth period, it is assumed that chicken dunk organic fertilizer is continuously decomposed and nitrogen as well as other nutrients becomes more available when plant is entering into flowering and seed formations phases. According to [21], nitrogen has function to accelerate the growth, to increase ear corn size, to increase protein content on cereal crops and to regulate the use of phosphorus, potassium and other nutrients. According to [8], nitrogen has function to accelerate the whole growth and to develop leave chlorophile which are very important for photosynthesis process. In addition, nitrogen also has function for the formation of protein, lipid and other organic compounds.

Application of chicken dunk organic fertilizer not only capable to increase sweet corn production, but also had positive impacts in term of improvement of soil physical, chemical and biological properties. Improvement of soil physical properties is achieved because organic matter (organic fertilizer) has function as adhesive of loose soil particles or aggregate stabilizer compound [5,19]. Improvement of soil chemical properties is achieved because organic matter (organic fertilizer) facilitates crop's root to penetrate deeper within soil so that it can absorb more water and nutrients, improve rhizosphere environment that can maintain nutrients, improve exudation by crop's roots that capable to increase soil organic matter decomposition as well as $\mathrm{N}$ mineralization [16]. Improvement of soil biological properties is achieved because organic matter provides energy source for most of soil's microorganisms [20].

Fertilizer of oil palm fresh bunches had produced the lowest growth and production than that of chicken dunk organic fertilizer. This was due to the fact that fertilizer of oil palm fresh bunches had imbalance nutrients which was shown by higher K availability than that of $\mathrm{N}$ and P. According to [28], availability of sufficient and balance nutrients had effect on metabolism process in crop tissues. Metabolism process is a process of 
development and degradation of nutrients and organic matters within crop. The lack of certain nutrients within crop can produce the negative effect, whereas excessive quantity of certain nutrients within crop can damage the crop's growth itself.

\section{Conclusion}

Treatment of chicken dunk organic fertilizer was capable to increase the growth and production of sweet corn crop in shallow lowland swamp with magnitude yield of 4.37 $\mathrm{kg} / \mathrm{plot}$.

\section{References}

1. T. Alihamsyah, Izzudin Noor, Tidal Lowland: Supporting of Food Tenacity and Agribusiness Growth Source, (Council of Agricultural Research and Development, 2003)

2. T. Alihamsyah, Development of Lowland Swamp Area for Agricultural Enterprise, (Council of Agricultural Research and Development, 2005).

3. D. Budianta, D. Ristiani. Soil Fertility Management, (Sriwijaya University, Press. Palembang, 2013)

4. F.T. Gardner, R.B. Pearce, R. L. Mitchell, Physiology of Crops., (2008)

5. R.F. Gonzales, L.R. Cooperband, Compost. Sci. Util., 10, 226 (2002)

6. N. Hakim, M.Yusuf, A.M. Lubis, N. Sutopo, M.R. Saul, M.A. Diha, Go Ban Hong, H.H. Bailey, Fundamentals of Soil Science, (Lampung University, 1986)

7. H. B. Jumin, Fundamentals of Agronomy, (Raja Grafindo Perkasa, Jakarta, 2005)

8. P. Lingga, Marsono, Guidance of Fertilizer Utilizaton, (Penebar Swadaya, Jakarta, 2008)

9. S.L. Margaretha, Ningsih, W. Subandi, Zubachtiroddin, Corn Response to N, $P$ and $K$ Fertilizers at Dry Land and Dry Climate (Cereal Crop Research, East Lombok, 2014)

10. N. Marlina, E.A. Saputro, N. Amir, Journal of Suboptimal Land, 1(2), 138 (2012)

11. N. Marlina, N. Gofar, N. Amir, B.A. Putra, $7^{\text {th }}$ National Seminar Proceeding of Indonesia Soil Conservation Society, (Palembang, 2013)

12. N. Marlina, N. Gofar, A. Halim, A.M. Rohim, Journal of Agricultural Science Agrivita, 36(1), 48 (2014)

13. N. Marlina, Syafrullah, Proceeding of National Seminar of Suboptimal Land, (Palembang, 2014)

14. N. Marlina, R.I.S. Syafrullah, Aminah, Gusmiatun, Rosmiah, Midranisiah, Y. Purwanti, Gribaldi, International Journal of Engineering Research Science \& Technology, 4(2), 100 (2015)

15. N. Marlina, R.I.S. Aminah, Rosmiah, L.R. Setel, Journal of Biosaintifika, 7(2), 136 (2015)

16. J.A.W. Morgan, G.D. Bending, P.J. White, J. Exp. Bot., 56, 1729 (2005)

17. A. Navioside, Y. Sugito, M. Dewani, Jurnal Agrivita, 24(2), 136 (2002)

18. Soil Research Center, Terms of Reference Type, (P3TT, Bogor, 1983)

19. H. Riley, R. Pommeresche, R. Eltun, S. Hansen, A. Korsaeth, Agric. Ecosyst. Environ., 124, 275 (2008) 
20. A. Saviozzi, R. Cardelli, P. Nkou, R. Levi Minzi, R. Riffaldi, Compost. Sci. Util., 14, 54 (2006)

21. G. Soepardi, Soil Properties and Characteristics, (Soil Science Department, 1983)

22. Soil Research Council, Analyses of Sol Chemistry, Plant, Water and Fertilizer, (Department of Agriculture, Jakarta, 2005)

23. R.D.M. Suriadikarta, D.A. Simanungkalit, Organic Fertlzer and Bofertilizer, (Agricultural Research and Development Council, Bogor, 2006)

24. R. Sutanto, Organic Framing, (Kanisius, Yogyakarta, 2002)

25. Y. Sutoro, Soeleman, Iskandar, Corn Crop Cultivation, (Research and Development Center for Food Crops, Bogor, 1988)

26. N. Syafrullah, Marlina, Gribaldi, R.I.S. Aminah, Midranisiah, G.A. Nasser, Gusmiatun, International Journal of Engineering Research Science \& Technology, 4(3), 1 (2015)

27. L.R. Widowati, Sri Widati, U. Jaenudin, W. Hartatik, The Effect of Organic Fertilizer Compost Enriched with Minerals and Biofertilizer on Soil Properties (Soil Research Council, 2005) 